Review

\title{
Sustainability-Oriented Business Model Evaluation-A Literature Review
}

\author{
Anika Süß *D, Kristina Höse and Uwe Götze
}

Citation: Süß, A.; Höse, K.; Götze, U. Sustainability-Oriented Business Model Evaluation-A Literature Review. Sustainability 2021, 13, 10908. https://doi.org/10.3390/su 131910908

Academic Editor: Guido Perboli

Received: 2 September 2021

Accepted: 28 September 2021

Published: 30 September 2021

Publisher's Note: MDPI stays neutral with regard to jurisdictional claims in published maps and institutional affiliations.

Copyright: (c) 2021 by the authors. Licensee MDPI, Basel, Switzerland. This article is an open access article distributed under the terms and conditions of the Creative Commons Attribution (CC BY) license (https:// creativecommons.org/licenses/by/ $4.0 /)$.
Faculty of Economics and Business Administration, Chemnitz University of Technology, 09111 Chemnitz, Germany; kristina.hoese@wiwi.tu-chemnitz.de (K.H.); uwe.goetze@wiwi.tu-chemnitz.de (U.G.) * Correspondence: anika.suess@wiwi.tu-chemnitz.de

\begin{abstract}
Since the need of sustainable development is indisputable, companies are forced to strive for resources, processes, and products that are sustainable. Thus, their business models as the main representation of their activities should be designed in an ecologically, economically, and socially beneficial way. However, designing and developing sustainable business models is closely linked to their evaluation. Sustainable business model evaluation as a vital part of business model development has been addressed in literature in the past with increasing frequency. As a consequence, the plethora of different approaches of sustainability-oriented business model evaluation calls for a systematic literature review. Thus, in this study, we reviewed existing articles on sustainabilityoriented business model evaluation and identified four main categories of evaluation methods: single indicators (I), indicator system/framework (II), simulation-based evaluation (III), and multi criteria decision-making (IV). By analyzing and structuring the proposed approaches, their benefits and limitations are revealed, pointing out gaps and future research needs for successfully designing and evaluating business models today and in the future.
\end{abstract}

Keywords: business model evaluation; sustainable business model evaluation; sustainability; sustainable business models; literature review; sustainability assessment

\section{Introduction}

While facing drastic global effects of climate change, growing population, and an ongoing pandemic, it seems obvious that present business practices are not sufficient for enabling a sustainable and bright future. Rethinking resource consumption and production conditions and taking actions for the achievement of Sustainable Development Goals [1] is more than ever relevant nowadays. Therefore, business sustainability is a highly important topic and accordingly already addressed in research [2]. However, present literature reveals a plethora of different approaches to consider sustainability within the development and evaluation of business models [3,4].

This raises the question, how to choose a suitable method for each individual evaluation task. Moreover, it impedes the application of such an evaluation for practitioners and at the same time hinders the development of sustainable business models, as well. To overcome this problem, this paper provides an overview on existing approaches of business model evaluation in order to enable the rethinking and developing of business models to achieve enhanced sustainability. For this reason, literature on sustainabilityoriented business model evaluation is reviewed in terms of methods used. Additionally, the methods used are structured to support the choice of a suitable one depending on the specific evaluation task.

In Section 2, an overview of sustainability and sustainability evaluation as well as business models and business model evaluation is given. After that, the method of the systematic literature review is presented in more detail (Section 3). The results of the literature review are presented in Section 4. There, the identified sustainability-related business model evaluation approaches are categorized and analyzed in more detail. The 
method (of literature review) as well as the results are discussed in Section 5. Finally, a conclusion (Section 6) completes the paper.

\section{State of the Art-Sustainability and Business Models}

\subsection{Sustainability and Sustainability Evaluation}

Sustainability is a term often applied and discussed in various contexts of economy, politics, and science, e.g., mobility, demographic development or climate change [5]. For a better understanding of the term sustainability, it seems to be necessary to refer to its historical development, e.g., VON CARLOWITZ' forest management principles, the Brundtland-Report and the Rio-Conference (for an overview see [5]). First thoughts about sustainability are based on VON CARLOWITZ, who claims for a sustainable forest management in 1713 [6]. In 1987, in the Brundtland-Report published by the World Commission on Environment and Development the term "sustainable development" was described as the necessity to meet the current generations' needs without putting future generations in a worse position [7,8]. Following this, in 1992 the participants of the United Nations Conference on Environment and Development in Rio de Janeiro negotiated and adopted documents to incorporate sustainability in a formal concern, which represents the beginning of implementing sustainability in policy [5,9]. Even though the importance of sustainability in economy, science and policy is undoubted, no clear and common definition of sustainability exists. However, for a holistic consideration of sustainable development the three dimensions of sustainability (economic, ecological, and social) need to be considered in a balanced way. Economic sustainability aims at the long-term economic continuity of a system (e.g., a company). Ecological sustainability has the same target in an ecological manner. Social sustainability considers systems in relation to human by addressing problems like discrimination among others [5].

However, how can the overall sustainability of systems be measured and assessed? GÖTZE ET AL. presented an overview of approaches for the assessment of sustainability on different levels-company, technology, product, and process [10]. Here, the sustainability balanced scorecard is mentioned as an approach considering all three dimensions of sustainability. However, the other approaches named there refer to only one or two dimensions of sustainability (e.g., life cycle costing-economic dimension, life cycle assessment-ecological dimension, social life cycle assessment-social dimension, life cycle engineering-economic and ecological dimensions). Concluding, it is not sufficient to choose only one of these concepts for an assessment of the overall sustainability. A solution approach for this problem is the life cycle sustainability assessment, first mentioned by ZHOU ET AL. [11], a concept proposing to integrate methods to assess particular dimensions of sustainability to a method for performing an overall assessment of sustainability $[12,13]$.

Several authors already performed integrated sustainability analyses for specific tasks (e.g., [14-16]). One possibility for a sustainability assessment is the usage of indicators/ratios. DAHLGREN AND AMMENBERG, for example, propose a set of economic, ecological, and social-related indicators (e.g., total cost of ownership, greenhouse gas emission savings, noise) to assess different bus technologies [16]. However, ratio systems seem to be more suitable than single indicators, as the relationship between different targets can be illustrated, among others [17]. The sustainability balanced scorecard, a ratio system including all sustainability dimensions in one concept, is applied by several authors (e.g., by [15] to analyze a Brazilian agricultural company). However, it should be mentioned that the Balanced Scorecard is a concept focusing on strategy implementation and management control [17] without having assessment as the main task. The life cycle sustainability assessment was also used by several authors to assess the sustainability-related performance of processes or products (for an overview of 21 case studies applying life cycle sustainability assessment in the manufacturing domain see [13]). One example is the case study of EKENER ET AL., who developed a life cycle sustainability assessment methodology by using multi criteria decision analysis to integrate the results of the assessments of each sustainability dimension [18]. 
GÖTZE ET AL. present a concept for the assessment of human-robot collaborations using a decision theory-based procedure model. For each sustainability dimension, they suggest target figures and methods or concepts for their determination. Regarding the economic dimension, the net present value is calculated by applying the net present value method. The ecological target figure, carbon footprint, is determined by analyzing the same input and output quantities as consulted for economic assessment in an ecological manner. For the social dimension, the ergonomic load is ascertained by application of key indicator method. A second social-related target figure, the acceptance by the employee, is considered by conducting interviews. Finally, the single target figures are weighted and afterwards aggregated to enable a holistic sustainability assessment. For that, GÖTZE ET AL. suggest to apply the utility value analysis to determine the utility value as sustainability target figure [14]. The methodology presented by GÖTZE ET AL. is accompanied by the idea to integrate methods referring to several sustainability dimensions to a holistic assessment of sustainability, similar to the concept of life cycle sustainability assessment.

As a conclusion, a variety of concepts and methods for sustainability assessment of companies, technologies, processes, and products does exist without having "the" one methodology that can by proposed for every case.

\subsection{Business Models and Their Evaluation}

The business model concept has become prevalent in the 1990s, driven by the growth of the Internet and E-Commerce, although business models have been an essential part of economic behavior for much longer $[19,20]$. With increasing importance, the number of definitions of the term business models increased as well. A compilation of definitions can be found in [21,22]. The different definitions can be clustered into two groups [23]: On the one hand, a business model can be understood as a description of the key principles of value creation on an abstract level (e.g., [24]); on the other hand, it is interpreted as the specific design how one company creates value in practice, i.e., in form of the realization of the business model [25]. Accepting the latter definition enables evaluating a specific business model and lays the ground for the following thoughts of this paper.

One point plenty of authors of business model definitions have in common is the use of a semantic structure to describe the different elements, sometimes within different dimensions, their definition of a business model contains. This is described by the term ontology and examples or variations can be found in [26,27], or the probably best known in [28]. OSTERWALDER started his business model ontology from four main areas or pillars (product, customer interface, infrastructure management, financial aspects) [28] and refined them on a more detailed level into nine business model elements. Together with PIGNEUR, a further developed version was published, namely the Business Model Canvas including the elements customer segments, value proposition, channels, customer relationships, revenue streams, key resources, key activities, key partnerships, and cost structure [24].

Many authors describe the process of developing an idea into a business model as well. According to [21,22], this process is divided into six steps: development of business model ideas (1), feasibility analysis (2), prototyping (3), decision-making (4), implementation (5), and monitoring and controlling (6). The order of these steps is rather a suggestion to follow, as business model development is an iterative process with many feedback loops. Along with that go many different evaluation steps throughout and linked with the business model development.

ZIEGENFUSS [29] gives an extensive overview of methods that can be used for the evaluation of business models. Therefore, a classification into qualitative, semi-quantitative, and quantitative methods is done. The methods are categorized depending on their focus of evaluation - the whole business model or specific dimensions of a business model (e.g., financial dimension) [29].

In the literature, many approaches evaluate business models qualitatively. One qualitative evaluation is proposed by [30], who summarized success factors of business models by the acronym NICE, considering the ability to create innovations (novelty), to 
protect strategic resources from competitors (lock-in), to complementarily use resources (complementarity), and to organize in a transaction cost-effective way (efficiency). HAMEL proposes different key success factors for the value of business models in order to evaluate them, addressing the ability to deliver customer benefits in an efficient way, the inimitability of the business model, the fit among the elements and the potential of generating above average-returns [25]. Although it might be worthy of discussion if the consideration of success factors is to be declared as an evaluation, it is at least a way to get a holistic idea of the business model and its potential. However, it should be combined with a quantitative evaluation [31].

A quantitative approach is presented by OSTERWALDER and PIGNEUR, who developed questions for each business model element basing on their ontology. To answer these questions, they propose a scale from one to five to measure e.g., customers' satisfaction or the substitutability of strategic resources [22].

Another quantitative performance indicator for evaluating business models is the net present value (NPV) [23]. Based on the NPV, SCHALLMO introduces the business model value that calculates the net monetary gain from the business model by discounting all estimated future cash inflows and outflows related to the business model [22,32]. Over the last years, the use of another method for simulating complex business activities, such as business models, and quantitatively estimating their success increased [31]: system dynamics uses equations to describe business model elements and the interdependencies among them over time [29,33]. ZIEGENFUSS suggests a model using system dynamics to describe and evaluate elements of business models and their interdependencies [29]. However, this approach does not focus on sustainability aspects.

Methods for business model evaluation are manifold, as shown above. Nonetheless, they largely have been focusing economic success and have been disregarding ecological or social responsibilities for a long time. To analyze the state-of-the-art of approaches aiming at an evaluation of business models from a more sustainability-centered view, a systematic literature review is conducted.

\section{Method}

The aim of this literature review is to identify publications that address the sustainabilityoriented evaluation of business models and to analyze these approaches. To get an overview of recent methodological developments and preliminary findings in business model evaluation, a systematic literature review was conducted, using a database-search-based methodology. Therefore, we identified relevant keywords and scientific databases to find suitable articles that address the topic of sustainability-oriented business model evaluation. After a bibliometric analysis, we scanned the results regarding titles and abstracts to choose the most relevant papers and analyzed them in detail.

We chose four different databases and searched on 1 October 2020 for literature with search terms given in Table 1 in the title, resulting in a list of 215 articles in total. After removing duplicates, 84 articles remained. Based on this result, a bibliometric analysis was conducted at the first.

The analysis of the publication time shows the beginnings of research on this topic around 14 years ago and a sharp increase over the last 6 years (see Figure 1). That implies that the need for sustainable business models and an approach to evaluate the sustainability of business models attract more and more attention, especially in research and presumably in business practices as well.

Figure 2 shows in which journals relevant paper were published, indicating a high amount of articles published in Journal of Cleaner Production and Sustainability, but there is also a large number of journals listed only once. The resulting 84 publications were studied, neglecting articles which are not written in English language, which are not accessible, or with a purpose other than evaluating business models or a deviating understanding of the terms business model, evaluation, or sustainability. Various articles deal with sustainability in terms of economic viability, neglect the social and environmental dimension and were 
excluded from our analysis for this reason. Other publications focus on reviewing other articles instead of presenting methodological approaches. These literature reviews were not included in the analysis itself, but the most relevant of them were screened and one could be used to identify further articles of interest [3]. Two of the articles cited there fulfilled the criteria (named above) and were added to the list (see Table 2). This step identified the most relevant publications resulting in a list of 18 articles. The procedure of the literature review is presented in Figure 3.

Table 1. Results of literature review.

\begin{tabular}{ccccc}
\hline & \multicolumn{4}{c}{ Platform } \\
\cline { 2 - 5 } “Business Model $^{*}$ "Sustainab* AND & EBSCO & ScienceDirect & Scopus & Web of Science \\
\hline evalua* $^{*}$ & 3 & 3 & 7 & 6 \\
\hline assess* $^{*}$ & 9 & 6 & 14 & 10 \\
\hline anal $^{*}$ & 18 & 10 & 30 & 25 \\
\hline review* $^{*}$ & 12 & 9 & 29 & 65 \\
\hline Total & 42 & 28 & 80 & \\
\hline Total without duplicates & \multicolumn{3}{c}{$\mathbf{8 4}$} \\
\hline
\end{tabular}

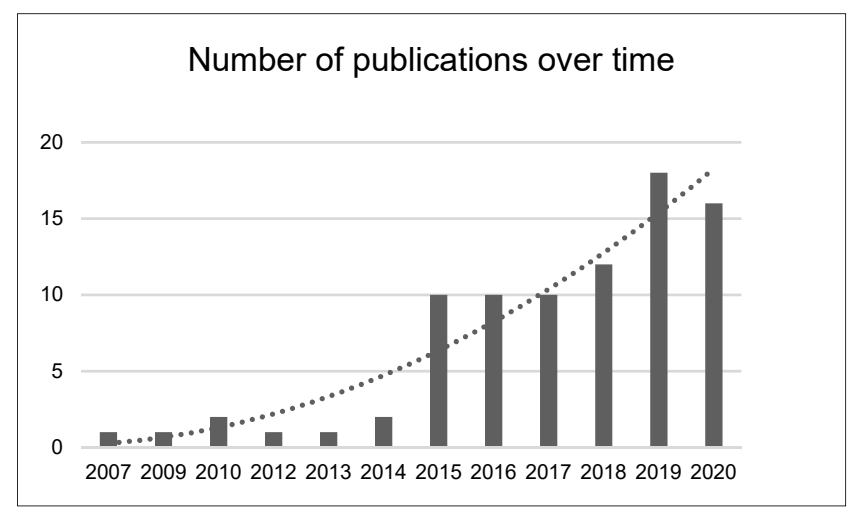

Figure 1. Number of resulting publications over time.

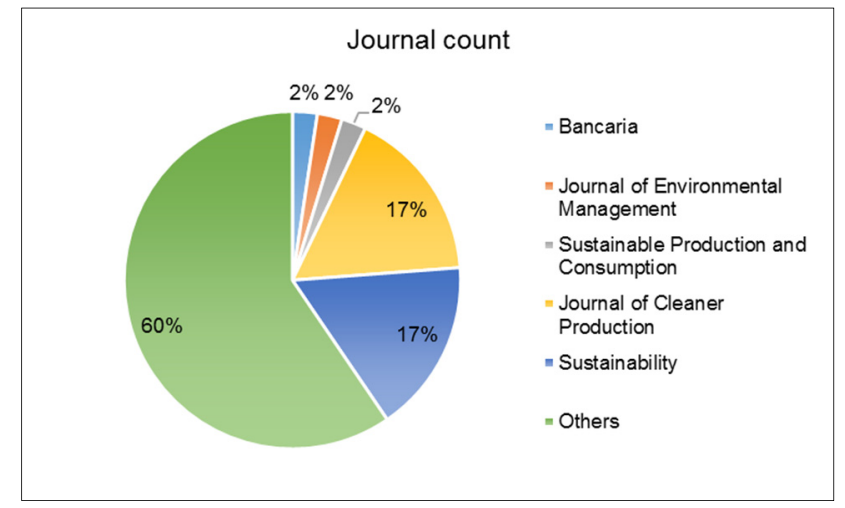

Figure 2. Journal count. 
Table 2. Resulting list of articles ( ${ }^{*}$ relevant primary sources identified in [3]).

\begin{tabular}{|c|c|c|c|c|}
\hline Ref. & Author(s) & Year & Title & Industry/Area \\
\hline$[34]$ & $\begin{array}{l}\text { Barbieri, R., Lopes } \\
\text { Santos, D.F. }\end{array}$ & 2020 & $\begin{array}{l}\text { Sustainable Business Models and } \\
\text { Eco-Innovation: A Life Cycle Assessment }\end{array}$ & Health \\
\hline$[35]^{*}$ & Bocken, N. et al. & 2015 & $\begin{array}{l}\text { Value mapping for sustainable business } \\
\text { thinking }\end{array}$ & General \\
\hline$[36]$ & $\begin{array}{l}\text { Broccardo, L., } \\
\text { Zicari, A. }\end{array}$ & 2020 & $\begin{array}{l}\text { Sustainability as a Driver for Value } \\
\text { Creation: A Business Model Analysis of } \\
\text { Small and Medium Enterprises in the } \\
\text { Italian Wine Sector }\end{array}$ & Utilities sector \\
\hline$[37]$ & Chambost, V., et al. & 2018 & $\begin{array}{c}\text { Systematic Assessment of Tritical—based } \\
\text { Biorefinery Strategies: Investment } \\
\text { Decisions for Sustainable Biorefinery } \\
\text { Business Models }\end{array}$ & Utilities sector \\
\hline$[38]^{*}$ & Díaz-Díaz, R. et al. & 2017 & $\begin{array}{l}\text { The Business Model Evaluation Tool for } \\
\text { Smart Cities: Application to Smart } \\
\text { Santander Use Cases }\end{array}$ & Public services \\
\hline [39] & Godina, R., et al. & 2020 & $\begin{array}{l}\text { Impact Assessment of Additive } \\
\text { Manufacturing on Sustainable Business } \\
\text { Models in Industry 4.0 Context }\end{array}$ & $\begin{array}{l}\text { Production } \\
\text { technologies }\end{array}$ \\
\hline$[40]$ & $\begin{array}{l}\text { Høgevold, N. M., } \\
\text { et al. }\end{array}$ & 2015 & $\begin{array}{l}\text { A Sustainable Business Model in Services: } \\
\text { An Assessment and Validation }\end{array}$ & Hotels \\
\hline$[41]$ & Hutchinson, D., et al. & 2012 & $\begin{array}{l}\text { An Assessment of the Early Stages of a } \\
\text { Sustainable Business Model in the } \\
\text { Canadian Fast Food Industry }\end{array}$ & Utilities sector \\
\hline$[42]$ & $\begin{array}{l}\text { Lüdeke-Freund, F., } \\
\text { et al. }\end{array}$ & 2017 & $\begin{array}{l}\text { Sustainability-Oriented Business Model } \\
\text { Assessment-A Conceptual Foundation }\end{array}$ & General \\
\hline [43] & Melkonyan, A., et al. & 2017 & $\begin{array}{l}\text { Sustainability Assessments and Their } \\
\text { Implementation Possibilities within the } \\
\text { Business Models of Companies }\end{array}$ & Utilities sector \\
\hline$[44]$ & Morgan, E. & 2015 & $\begin{array}{l}\text { 'Plan A': Analysing Business Model } \\
\text { Innovation for Sustainable Consumption } \\
\text { in Mass-Market Clothes Retailing }\end{array}$ & Fashion \\
\hline [45] & Moschetti, R., et al. & 2018 & $\begin{array}{l}\text { Performing Quantitative Analyzes } \\
\text { towards Sustainable Business Models in } \\
\text { Building Energy Renovation Projects: } \\
\text { Analytic Process and Case Study }\end{array}$ & Construction \\
\hline [46] & Müller, N. A., et al. & 2016 & $\begin{array}{c}\text { Business Model in the Context of } \\
\text { Sustainable Urban Water } \\
\text { Management-A Comparative } \\
\text { Assessment between Two Urban Regions } \\
\text { in Australia and Germany }\end{array}$ & Utilities sector \\
\hline [47] & Nosratabadi, S., et al. & 2020 & $\begin{array}{l}\text { Sustainable Banking; Evaluation of the } \\
\text { European Business Models }\end{array}$ & Banking \\
\hline [48] & Rotondo, F., et al. & 2019 & $\begin{array}{l}\text { The Social Side of Sustainable Business } \\
\text { Models: An Explorative Analysis of the } \\
\text { Low-Cost Airline Industry }\end{array}$ & Mobility \\
\hline [49] & Wagner, O., et al. & 2020 & $\begin{array}{c}\text { Surviving the Energy Transition: } \\
\text { Development of a Proposal for Evaluating } \\
\text { Sustainable Business Models for } \\
\text { Incumbents in Germany's Electricity } \\
\text { Market }\end{array}$ & Utilities sector \\
\hline
\end{tabular}


Table 2. Cont.

\begin{tabular}{|c|c|c|c|c|}
\hline Ref. & Author(s) & Year & Title & Industry/Area \\
\hline [50] & Watanabe, E. H., et al. & 2016 & $\begin{array}{l}\text { An Emerging Industrial Business Model } \\
\text { Considering Sustainability Evaluation } \\
\text { and Using Cyber Physical System } \\
\text { Technology and Modelling Techniques }\end{array}$ & $\begin{array}{l}\text { Production } \\
\text { technologies }\end{array}$ \\
\hline [51] & Zhao, X., et al. & 2017 & $\begin{array}{l}\text { AHP-ANP-Fuzzy Integral Integrated } \\
\text { Network for Evaluating Performance of } \\
\text { Innovative Business Models for } \\
\text { Sustainable Building }\end{array}$ & Construction \\
\hline
\end{tabular}

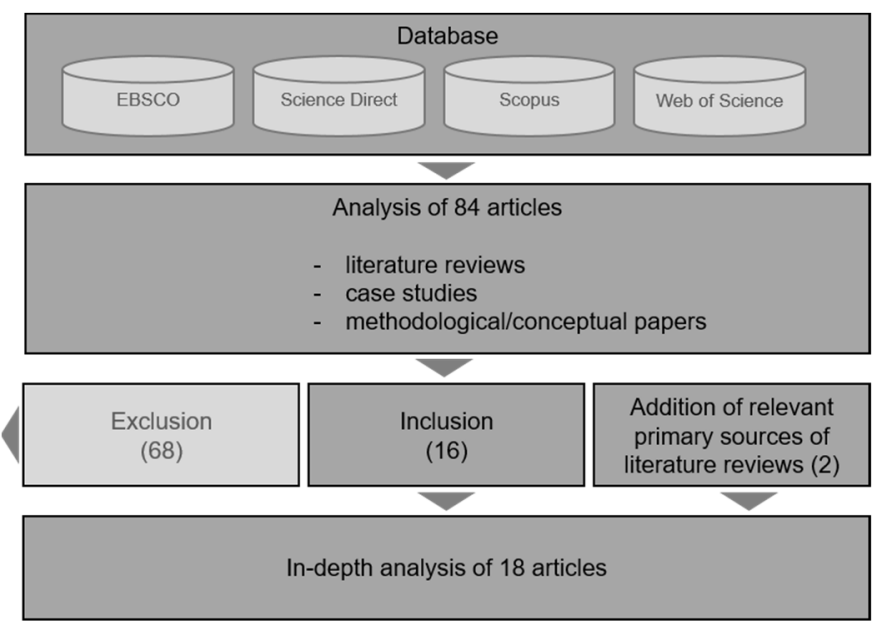

Figure 3. Method of literature review.

The remaining papers were analyzed regarding several criteria. First, they were categorized into general papers and papers with specific application (areas). Afterwards, the proposed or applied methodology for a sustainability-oriented evaluation of business models or elements of business models of each paper was analyzed in more detail (see Section 4).

\section{Results}

The resulting list includes 18 scientific articles dealing with the sustainability-oriented evaluation of business models, as shown in Table 2. Remarkably, most of the articles refer to specific contexts or industries, e.g., health industry, utilities sector, or fashion industry. Thus, there are only two articles solely conceptual or without an example of application.

Referring to the remaining 18 articles, we performed an in-depth analysis of the evaluation methods proposed and/or applied in each paper. Thereby, different evaluation types were identified and were used subsequently to structure our findings.

All papers deal with the three sustainability dimensions (economic, ecological, social), due to our definition of the term sustainability (see Section 2.1). Next to the sectors that are focused by the papers, the papers were analyzed concerning the methods used to assess the sustainability of business models. We distinguished the following categories: single indicators (I), indicator system/framework (II), simulation-based evaluation (III), and multi criteria decision-making (MCDM) (IV). Some of the papers using single indicators (category I) refer to argumentative analyses based on business model ontologies, such as presented in Section 2.2. There, the ontologies build the frame for the chosen indicators (e.g., [40]) Some of the frameworks (category II) regard to one specific instrument (e.g., Balanced Scorecard [39]), others connect different instruments (e.g., Balanced Scorecard with an ontology [42]). Simulation-based evaluation methods (category III) apply indicators as well. However, they focus on the analysis of interdependencies using simulations and 
therefore, they are seen as an own category, here. Additionally, they are suggested for evaluating business models in general, as discussed in Section 2.2 (referring to [29]). Finally, papers using MCDM (category IV) are considered. The approaches of this category base on indicators, as well. However, they especially have in common, that they apply a MCDM method which usually addresses the issue of multiple targets, in this case regarding the dimensions of sustainability [32].

As a result, the selected 18 papers were classified with one of the four categories (I, II, III, IV), as shown in the following Table 3.

Table 3. Classification of sustainability-oriented business model evaluation methods.

\begin{tabular}{|c|c|c|}
\hline Method & Description & References \\
\hline \multicolumn{3}{|c|}{ (I) Single Indicators } \\
\hline Single Indicator based evaluation & Evaluation based on sustainability related indicators & {$[34,36,45,46,48-50]$} \\
\hline $\begin{array}{l}\text { Argumentative analysis based on } \\
\text { Business Model Ontologies }\end{array}$ & $\begin{array}{l}\text { Argumentative analysis based on indicators derived } \\
\text { from business model elements }\end{array}$ & {$[35,40,41,44]$} \\
\hline \multicolumn{3}{|c|}{ (II) Indicator System/Framework } \\
\hline Balanced Scorecard & $\begin{array}{l}\text { Balanced scorecard structure for evaluating economic, } \\
\text { ecological, and social impacts }\end{array}$ & [39] \\
\hline SUST-BMA & $\begin{array}{l}\text { Based on a business model logic and Balanced } \\
\text { Scorecard structure }\end{array}$ & [42] \\
\hline Value of Business Model (VBM) & $\begin{array}{l}\text { Business Model Canvas Structure complemented by } \\
\text { social and ecological elements, indicators for some } \\
\text { elements }\end{array}$ & {$[38]$} \\
\hline \multicolumn{3}{|c|}{ (III) Simulation based evaluation } \\
\hline System Dynamics & $\begin{array}{l}\text { Using System Dynamics to analyze interdependencies } \\
\text { using simulation methods }\end{array}$ & [43] \\
\hline \multicolumn{3}{|c|}{ (IV) Multi Criteria Decision Making (MCDM) } \\
\hline Utility Value Analysis & Incorporating and weighting a set of criteria & [37] \\
\hline Analytical Hierarchy Process & $\begin{array}{l}\text { Prioritizing business model components and/or } \\
\text { criteria in terms of sustainability }\end{array}$ & {$[47,51]$} \\
\hline
\end{tabular}

The first evaluation type comprises Single Indicators (I). Apparently, most single indicators are derived from the context of the business model. For example, to evaluate sustainability of business models of the urban water management, indicators like water sources, degree of cost pressure, degree of customer participation, or water costs are used [46]. Another example is the evaluation of the business model of building renovation projects based on specific indicators, such as indoor air quality in the renovated building, total life cycle costs for building owners, or the direct life cycle energy related to the building renovation [45]. The use of such specific indicators enables an evaluation or comparison of similar business models in the same scope, but makes it harder to apply the method to another industry. Some more general indicators are used by BROCCARDO and ZICARI, who compare business models of family and non-family owned businesses in the Italian wine sector by reference to profitability, financial structure, ownership, patents, and tangible assets, among others [36]. Another example is the evaluation of different airlines' business models by ROTONDO using criteria for market (e.g., who is addressed with value created?), structure (e.g., the role of employees), and value proposition (e.g., whether social sustainability is part of the BM) [48]. By using general indicators, the evaluation method can be applied across different industries or areas.

In some articles, single indicators are directly associated to sustainability dimensions $[34,45]$, e.g., for social performance the indicator accidents at work, for economic performance the ROI, and for ecological performance the GHG emissions are used as indi- 
cators for evaluation [34]. This enables a holistic view and it is easier to ensure that all three dimensions are addressed adequately. Others do not explicitly classify proposed indicators but at least support the conclusion that indicators might be derived from a triple bottom line approach [49]. Beside traditional sustainability dimensions, some authors consider technical aspects, as well, to give a broader overview of the business model [50]. Another possible way of single indicator-based evaluating is to base the evaluation on existing business model ontologies and their elements. Some authors use them to derive indicators or criteria from the elements. To evaluate, to which extent the criteria are met, a logical-argumentative analysis is often used $[40,41,44]$. HøGEVOLD ET AL. have done an analysis of a Scandinavian hotel chain's business model. Their analysis bases on a "business sustainability model" [40] from which evaluation criteria are derived, such as the company's vision and mission, the connection to planet earth in terms of the application of the triple bottom line or the choice of producers and suppliers. In their study, the authors argumentatively analyze characteristics and actions the company takes, suitable to each criterion The last-mentioned criterion e.g., is expressed by the extent of using environmentally friendly and socially responsible textiles by checking whether their suppliers apply ISO standards. HUTCHINSON ET AL. evaluate the business model of a Canadian café and bake shop chain by investigating its (1) driving forces; (2) purchasing policies; (3) value-adding processes; (4) intermediaries and transport; (5) retail practices; (6) marketplace; and (7) the natural environment [41]. MORGAN derives criteria from the four main pillars of the business model canvas and maps them to core drivers of business cases for sustainability. In that way, sustainability aspects are ought to be considered. However, the main limitation of this method is that the evaluation is not primarily focused on sustainability, as the effects the core drivers have on the business model are analyzed regarding economic benefits. Therefore, not the sustainability of the business model is evaluated, but the effects perceived sustainable actions have on the existing business model [44]. Another approach of an argumentative single indicator-based evaluation is presented by BOCKEN ET AL. [35]. They developed the value mapping tool for qualitatively evaluating and screening business model options to compare potential business model innovations and strategies. The tool takes a multi-stakeholder perspective and considers value in multiple forms: value captured, value destroyed, value missed, and new value opportunities. Based on these aspects, the value mapping tool can facilitate comparing business model ideas and accelerate decision-making [35].

The main shortfall of an evaluation which is based on single indicators, whether they are derived from sustainability dimensions or from a business model ontology, is the neglect of interdependencies between business model elements, (evaluation) criteria and/or targets. To overcome this problem, other approaches use indicators in indicator systems or frameworks (II). They are intended to show relations between different sustainability-related targets, elements, and/or (evaluation) criteria (expressed by indicators) that are structured in form of a system [39], conceptual framework [42], or a tool [38] among others. Some of them use business model ontologies/logics like the business model canvas or others (e.g., [38,42]) and/or systems like the balanced scorecard [39,42].

GODINA ET AL. propose to use the balanced scorecard to assess the influence of additive manufacturing on business models. They define economic, ecological, and socialrelated balanced scorecard perspectives (traditional perspectives learning and growth, process, market, financial are considered for each dimension of sustainability resulting in 12 dimensions) [39]. Their ideas base on the model of NiCOLETTI JUNIOR ET AL., who focused on the relation between sustainability dimensions and balanced scorecard perspectives [52]. Afterwards, GODINA ET AL. discuss impacts of additive manufacturing within the dimensions of the balanced scorecard (e.g., cost reduction is a benefit categorized into the economic part of financial dimension, energy efficiency improvements are benefits categorized into the environmental (or ecological) part of the financial dimension). Regarding the social part, indicators for each balanced scorecard dimension are deducted, e.g., work satisfaction as part of the learning and growth perspective [39]. 
LÜDEKE-FREUND ET AL. present a conceptual framework for sustainability oriented business model assessment (SUST-BMA), which includes perspectives of the balanced scorecard, as well. The first element of the approach is the business model concept in form of five business model logics (marketing logic, capabilities and resources logic, financial logic, production logic contextual logic). The second element is the sustainability balanced scorecard (SBSC) with the financial, customer, internal process, learning growth and nonmarket perspective (basing on FIGGE ET AL. [53]). Both elements are matched by combining each logic with one perspective (e.g., financial logic and financial perspective, production logic and internal process perspective) to identify outcomes in form of created value. To determine particular values for the assessment, using indicators, e.g., as proposed in the Global Reporting Initiative (GRI)-framework [54] is suggested [42].

DÍAZ-DíAZ ET AL. develop a business model evaluation tool for smart cities, which is based on a business model logic as well. For this, they use the business model canvas complemented by new elements—social \& environmental cost and social \& environmental benefit [24] - to enable the reference to a sustainability-oriented ontology. For some of the elements of this business model canvas (e.g., cost structure, revenue streams, social and environmental costs, value proposition) they create parameters (e.g., they ask if the price of the product/service is better than for other alternatives as part of value proposition). Additionally, they determine potential "qualifications" for them (in the example of the value proposition, a value between 0 which means no and 1 which stands for a clearly positive answer). Finally, they determine a Value of the Business Model (VBM) by creating a formula that includes the results of the parameters or potential qualifications of the considered business model elements. Based on this value, it is possible to compare different business models and make strategic decisions [38].

Next to the indicator-based evaluation in form of single indicators or indicators in indicator systems or frameworks, indicators used within simulation-based evaluation approaches (III) exist. MELKONYAN ET AL. applied system dynamics for their analysis of business models and sustainability in the area of energy utility. For the simulation, they created causal loop diagrams (CLD) and, as a following, a stock and flow diagram (SFD) was analyzed [43].

Finally, methods of MCDM (IV) are identified as an option to evaluate business models in terms of sustainability. CHAMBOST ET AL. presented an approach aiming at supporting the decision-making for an implementation of a biorefinery-based strategy. Therefore, they identify and weight a set of economic, ecological, and competiveness-oriented criteria. Afterwards, an utility value is calculated for each alternative (each strategy) to identify the alternative leading to the most sustainable business model [37]. Another method of MCDM applied in the context of business models and sustainability $[47,51]$ is the analytical hierarchy process (AHP). NOSRATABADI ET AL. assessed the sustainability performance of 16 banks. Therefore, business model elements (e.g., value proposition, business processes) are prioritized in terms of their significance for sustainability by applying AHP. The identification of the business model elements is supported by using the Delphi method before [47]. ZHAO ET AL. assessed the business models for sustainable building. They identified performance criteria of business models (e.g., environmental performance, direct financial benefit) and indicators for them (e.g., shareholders return and annual growth rate of return as indicators for direct financial benefit). AHP as well as analytic network process (ANP) methods are applied to analyze the interdependencies among these criteria as well as their weights [51]. All these approaches use indicators for evaluation, as well.

This overview shows a wide range of business model evaluation methods with regard to sustainability, even though the literature review has been narrowed down to only 18 articles. In the following, the results of this work are discussed.

\section{Discussion}

This paper gives an overview of existing sustainability-related business model evaluation approaches. However, different issues arise with this review, which are two-fold: 
On the one hand, there are methodological limitations to our research (A), with respect to the following aspects: the choice of databases and search terms as well as criteria for inand exclusion of articles, the classification of the identified methods presented in the articles. On the other hand, the methods presented and applied within the identified articles themselves are worth being discussed, as well (B), with respect to the following aspects: interpretation of the term evaluation, scope of evaluation, limitation of approaches within the four categories (I, II, III, IV), choice of indicators and methods, and cross-dimensional evaluation methods.

(A) First, the methodological issues of the own study are discussed: By performing the literature review we could derive a traceable overview and interesting insights. Nevertheless, our work is not free of limitations. This paper is limited to the selected search terms and databases. The use of additional search terms could have broadened the scope of the analysis. However, they were chosen aligned with our understanding of the terms sustainability and business models. Regarding sustainability, we decided to include only articles that consider all three dimensions. In case methods basing on single dimensions should be analyzed, search terms like economic, ecological and/or social should been used along with evaluation etc. Additionally, other data bases could have been used, e.g., Google Scholar. Moreover, only English literature was taken into consideration.

Another point of discussion regarding the method refers to the classification of the identified methods. Generally, methods could be classified regarding the scope, the purpose, the target figure, and the type of the evaluation (among others). We decided to classify according to the type of the method and distinguish between four categories: single indicators (I), indicator system/framework (II), simulation based evaluation (III), and MCDM (IV). First, the identified types are not completely independent, as all of the evaluation methods base on indicators to a certain extent. Second, a classification according to the scope of evaluation could have been reasonable, differentiating between the whole business model and components/elements under evaluation. However, we intended to focus on the analysis of evaluation methods for whole business models and classified them according to the type.

(B) The second issue addresses the methods presented and applied within the articles and comprises several issues, which are to be discussed below:

Interpretation of the term evaluation: The term evaluation itself is sometimes perceived quite differently. Referring to the purpose, authors differentiate, whether solely modelling the relationships of business model elements is already seen as part of an evaluation, or it is mandatory that the evaluation includes rules for decision-making. Moreover, it varies in which stage of business model development the method can be applied: either it is used for an evaluation at an early stage of developing a business model or it requires data of a certain level of detail and is therefore suitable for a later stage of business model development. Therefore, the purpose of evaluation should be determined and based on this, accordingly the understanding of the term evaluation as well as the method that serves this purpose is chosen.

Scope of evaluation: Some presented approaches of business model evaluation rely on the assumption that a sustainable product (as the value proposition and core of the business model) leads to a sustainable business model by necessity [45] and only this part of the business model needs to be especially evaluated. However, BOCKEN et al. (2014) showed the variety of possibilities to obtain sustainable business models and although these are clearly linked to areas such as sustainable manufacturing and design, the business model concept allows for a wider view [2]. Following this idea, it seems apparent that evaluating only one part of the business model is not expedient for a holistic sustainability assessment, considering manifold effects on economy, environment, and society. Additionally, all elements of the business models should be analyzed from a long-term life cycle-oriented perspective.

Limitations of approaches within the four categories $(I, I I, I I I, I V)$ : The next point refers to the approaches used in the analyzed papers. As already mentioned in Section 4, the sole use of 
single indicators (I) impedes the consideration of interdependencies between sustainabilityrelated targets, elements, and/or (evaluation) criteria that are determined by indicators. This can be a reason to rather use a framework instead of single indicators for evaluating. In category II, two approaches use the balanced scorecard as a part of evaluation [39,42]. The information recorded and displayed in a balanced scorecard provides a comprehensive information base for a holistic sustainability assessment of business models. However, the balanced scorecard concept was originally designed as a means of strategy implementation and controlling the activities of businesses-and not for evaluation purposes. The third article of this category presents the so-called value of business model as the result of a formula that jointly considers business model elements as parameters. It is a debatable point whether this formula is devised feasibly but it enhances transparency and traceability of decision-making. Approaches of category III refer to system dynamics to evaluate the sustainability of business models. However, system dynamics is well-suited for describing relationships but may lack in an evaluation following the abovementioned understanding. The last category (IV) comprises the utility value analysis, which is easy to apply but bears the risk of double counting the same effects if not applied correctly, and the analytical hierarchy process, that involves a considerable effort for data collection but seams suitable for an elaborated evaluation (more information about advantages and disadvantages of MCDM methods can be found in [32]). Summarizing, all above-mentioned approaches have limitations that need to be considered when choosing the most suitable evaluation method for each case.

Choice of indicators and methods: Some indicator-based evaluation approaches use specific indicators [45,46], others use general indicators and therefore provide a more general evaluation approach [48]. While the approaches of the first group can hardly be adapted to cases from other industries or areas, they allow for a custom-made and detailed evaluation of the business model. It appears in both cases, that indicators are not matched to the dimensions of sustainability. However, to provide a holistic sustainability-oriented evaluation, it should be considered to derive the indicators directly from the economic, ecological, and social dimensions. In that way, it is avoided that one dimension is neglected or unintentionally weighed more than the others are. Additionally, the state-of-the-art of the dimension-specific evaluation methods should be considered, e.g., by using the net present value method for the economic assessment or the life cycle assessment for the ecological evaluation and the respective indicators derived from the method.

Cross-dimensional evaluation methods: Using dimension-specific methods for evaluation bears the risk of data inconsistencies between the single evaluation parts. It can be challenging to align the scope of the individual economic, ecological, and social evaluation. Additionally, conducting three single assessments equals a triplication of work. To avoid this, a cross-dimensional evaluation could be useful, considering the interdependencies between the individual sustainability dimensions. A systematic procedure model could be applied or the use of life cycle assessment could give directions for a subsequent joint sustainability evaluation of business models.

\section{Conclusions}

The present research contributes to the literature on sustainability-related business model evaluation by presenting a structured overview of the state-of-the-art of existing methods. To address this, a systematic literature was conducted. The focus of the analysis was laid on the presented and applied methods of sustainability-oriented business model evaluation. The identified methods were structured into four categories. Analyzing the existing literature on sustainability-related business model evaluation showed the variety of already established approaches and the need of refinement regarding the issues elaborately discussed above.

Further research could conduct a literature review similar to ours, but focus on different search terms (e.g., circular business models, triple layered business model, economic, ecological and/or social, along with evaluation and/or assessment, analysis, review) or 
data bases (e.g., Google Scholar, Wiley Online) or analyze the results based on other criteria (A). Furthermore, the presented methods within the chosen articles could be elaborated (B). For example, a systematic procedure model or the use of life cycle assessment should be considered as possible starting point in future research toward a methodology of integrated sustainability evaluation. Such research could address the issue of weighting and aggregating of the single dimension-related results, as well. Basic support for such aggregation is provided by MCDM methods such as analytic hierarchy process or utility value analysis. Furthermore, the balance of economic-, ecological-, and social-oriented indicators should be considered as well as the determination of the outcomes of the indicators.

Author Contributions: Conceptualization, A.S. and K.H.; methodology, A.S. and K.H.; validation, A.S. and K.H.; formal analysis, A.S. and K.H.; resources, A.S. and K.H.; data curation, A.S. and K.H.; writing-original draft preparation, A.S. and K.H.; writing-review and editing, A.S., K.H. and U.G.; visualization, A.S. and K.H.; supervision, U.G. All authors have read and agreed to the published version of the manuscript.

Funding: The publication of this article was funded by Chemnitz University of Technology.

Conflicts of Interest: The authors declare no conflict of interest.

\section{References}

1. UNDP Sustainable Development Goals. Available online: https://www.undp.org/sustainable-development-goals (accessed on 25 August 2021).

2. Bocken, N.M.P.; Short, S.W.; Rana, P.; Evans, S. A literature and practice review to develop sustainable business model archetypes. J. Clean. Prod. 2014, 65, 42-56. [CrossRef]

3. Schoormann, T.; Kaufhold, A.; Behrens, D.; Knackstedt, R. Towards a typology of approaches for sustainability-oriented business model evaluation. Lect. Notes Bus. Inf. Process. 2018, 320, 58-70.

4. Sinkovics, N.; Gunaratne, D.; Sinkovics, R.R.; Molina-Castillo, F.-J. Sustainable Business Model Innovation: An Umbrella Review. Sustainability 2021, 13, 7266. [CrossRef]

5. Pufé, I. Nachhaltigkeit, 3rd ed.; UVK Verlagsgesellschaft mbH mit UVK/Lucius: Konstanz, München, 2017; ISBN 9783838587059.

6. von Carlowitz, H.C. Sylvicultura Oeconomica oder Haußwirthliche Nachricht und Naturmäßige Anweisung zur Wilden Baum-Zucht; Braun: Leipzig, Germany, 1713.

7. Paul, B.D. A history of the concept of sustainable development: Literature review. Ann. Univ. Oradea, Econ. Sci. Ser. 2008, 17, 576-580.

8. WCED. World Commission on Environment and Development Our common future. Our Common Future 1987, $17,1-19$.

9. United Nations Report of the United Nations Conference on Environment and Development; United Nations Digital Library: New York, NY, USA, 1993; Volume II, ISBN 9211004985.

10. Götze, U.; Peças, P.; Richter, F. Design for eco-efficiency-a system of indicators and their application to the case of moulds for injection moulding. Procedia Manuf. 2019, 33, 304-311. [CrossRef]

11. Zhou, Z.; Jiang, H.; Qin, L. Life cycle sustainability assessment of fuels. Fuel 2007, 86, 256-263. [CrossRef]

12. Richter, F.; Schramm, A.; Götze, U. Life Cycle Sustainability Assessment-Concept and Methods. In Managerial Challenges of the Contemporary Society; Risoprint: Cluj-Napoca, Romania, 2019; Volume 12, pp. 45-51.

13. Schramm, A.; Richter, F.; Götze, U. Life Cycle Sustainability Assessment for manufacturing-Analysis of existing approaches. Procedia Manuf. 2020, 43, 712-719. [CrossRef]

14. Götze, U.; Schildt, M.; Mikus, B. Methodology for manufacturing sustainability evaluation of human-robot collaborations. Int. J. Sustain. Manuf. 2020, 4, 365. [CrossRef]

15. Araújo, L.; Oliveira, H.; Gomes, L. Sustainability Balanced Scorecard for a Brazilian agricultural and livestock company. E3S Web Conf. 2020, 159, 04005. [CrossRef]

16. Dahlgren, S.; Ammenberg, J. Sustainability Assessment of Public Transport, Part II-Applying a Multi-Criteria Assessment Method to Compare Different Bus Technologies. Sustainability 2021, 13, 1273. [CrossRef]

17. Götze, U.; Krönert, S.; Mikus, B. Kennzahlensysteme als Instrumente des Produktionscontrolling. Der Betriebswirt 2010, 51, 10-17. [CrossRef]

18. Ekener, E.; Hansson, J.; Larsson, A.; Peck, P. Developing Life Cycle Sustainability Assessment methodology by applying valuesbased sustainability weighting-Tested on biomass based and fossil transportation fuels. J. Clean. Prod. 2018, 181, 337-351. [CrossRef]

19. Teece, D.J. Business models, business strategy and innovation. Long Range Plan. 2010, 43, 172-194. [CrossRef]

20. Zott, C.; Amit, R.H.; Massa, L. The Business Model: Recent Developments and Future Research. SSRN Electron. J. 2011, 37, 1019-1042. [CrossRef]

21. Wirtz, B.W. Business Model Management, 2nd ed.; Springer Nature Switzerland AG: Cham, Switzerland, 2020; ISBN 9783030480165. 
22. Schallmo, D.R.A. Geschäftsmodelle Erfolgreich Entwickeln und Implementieren; Springer: Berlin/Heidelberg, Germany, 2013; ISBN 978-3-642-37993-2.

23. Götze, U.; Rehme, M. Bewertung innovativer Geschäftsmodelle bei sich wandelnden Wertschöpfungsstrukturen. Analyse-, Prognose-und Gestaltungsrahmen sowie die Anwendung auf die Ladeinfrastruktur für Elektrofahrzeuge. Z. Gesamte WertschöPfungskette Automob. 2013, 4, 27-37.

24. Osterwalder, A.; Pigneur, Y. Business Model Generation: A Handbook for Visionaries, Game Changers and Challengers; John Wiley and Sons, Inc.: Hoboken, NJ, USA, 2010; ISBN 978-0470-87641-1.

25. Hamel, G. Leading the Revolution. How to Thrive in Turbulent Times by Making Innovation a Way of Life; Harvard Business Press: Boston, MA, USA, 2000; ISBN 1591391466.

26. Bouwman, H.; Faber, E.; Haaker, T.; Kijl, B.; De Reuver, M. Conceptualizing the STOF model. In Mobile Service Innovation and Business Models; Springer: Berlin/Heidelberg, Germany, 2008; pp. 31-70. ISBN 9783540792376.

27. Akkermans, J.M.; Gordijn, J. Value-based requirements engineering: Exploring innovative e-commerce ideas. Requir. Eng. 2003, 8, 114-134. [CrossRef]

28. Osterwalder, A. The Business Model Ontology—A Proposition in a Design Science Approach; Universite de Lausanne: Lausanne, Switzerland, 2004; ISBN 0071392319.

29. Ziegenfuß, K. Bewertung Innovativer Geschäftsmodelle-Entwicklung eines Simulationsmodells und Anwendung auf die Bedarfsabhängige Funktionserweiterung im Vernetzten Fahrzeug; Readbox Publishing GmbH: Dortmund, Germany, 2021; ISBN 978-3-96100-128-6.

30. Amit, R.; Zott, C. Value creation in e-business. Strateg. Manag. J. 2001, 22, 493-520. [CrossRef]

31. Heim, R.; Linden, M. Konzeption eines Rahmenwerks zur Gestaltung und Bewertung von Geschäftsmodellen; Mercator School of Management: Duisburg, Germany, 2012.

32. Götze, U.; Northcott, D.; Schuster, P. Investment Appraisal-Methods and Models, 2nd ed.; Springer: Berlin/Heidelberg, Germany, 2015; ISBN 9783642334368.

33. Barabba, V.; Huber, C.; Cooke, F.; Pudar, N.; Smith, J.; Paich, M. A Multimethod Approach for Creating New Business Models: The General Motors OnStar Project. Interfaces 2002, 32, 20-34. [CrossRef]

34. Barbieri, R.; Santos, D.F.L. Sustainable business models and eco-innovation: A life cycle assessment. J. Clean. Prod. 2020, 266, 121954. [CrossRef]

35. Bocken, N.M.P.; Rana, P.; Short, S.W. Value mapping for sustainable business thinking. J. Ind. Prod. Eng. 2015, 32, 67-81. [CrossRef]

36. Broccardo, L.; Zicari, A. Sustainability as a driver for value creation: A business model analysis of small and medium entreprises in the Italian wine sector. J. Clean. Prod. 2020, 259, 120852. [CrossRef]

37. Chambost, V.; Janssen, M.; Stuart, P.R. Systematic assessment of triticale-based biorefinery strategies: Investment decisions for sustainable biorefinery business models. Biofuels, Bioprod. Biorefining 2018, 12, S9-S20. [CrossRef]

38. Díaz-Díaz, R.; Muñoz, L.; Pérez-González, D. The Business Model Evaluation Tool for Smart Cities: Application to SmartSantander Use Cases. Energies 2017, 10, 262. [CrossRef]

39. Godina, R.; Ribeiro, I.; Matos, F.; Ferreira, T.B.; Carvalho, H.; Peças, P. Impact Assessment of Additive Manufacturing on Sustainable Business Models in Industry 4.0 Context. Sustainability 2020, 12, 7066. [CrossRef]

40. Høgevold, N.M.; Svensson, G.; Padin, C. A sustainable business model in services: An assessment and validation. Int. J. Qual. Serv. Sci. 2015, 7, 17-33. [CrossRef]

41. Hutchinson, D.; Singh, J.; Walker, K. An assessment of the early stages of a sustainable business model in the Canadian fast food industry. Eur. Bus. Rev. 2012, 24, 519-531. [CrossRef]

42. Lüdeke-Freund, F.; Freudenreich, B.; Schaltegger, S.; Saviuc, I.; Stock, M. Sustainability-Oriented Business Model Assessment-A Conceptual Foundation. In Analytics, Innovation, and Excellence-Driven Enterprise Sustainability; Palgrave Macmillan US: New York, NY, USA, 2017; pp. 169-206.

43. Melkonyan, A.; Gottschalk, D. Sustainability assessments and their implementation possibilities within the business models of companies. Sustain. Prod. Consum. 2017, 12,1-15. [CrossRef]

44. Morgan, E. Plan A: Analysing Business Model Innovation for Sustainable Consumption in Mass-Market Clothes Retailing. J. Corp. Citizsh. 2015, 2015, 73-98. [CrossRef]

45. Moschetti, R.; Brattebø, H.; Skeie, K.S.; Lien, A.G. Performing quantitative analyses towards sustainable business models in building energy renovation projects: Analytic process and case study. J. Clean. Prod. 2018, 199, 1092-1106. [CrossRef]

46. Müller, N.A.; Marlow, D.R.; Moglia, M. Business model in the context of Sustainable Urban Water Management-A comparative assessment between two urban regions in Australia and Germany. Util. Policy 2016, 41, 148-159. [CrossRef]

47. Nosratabadi, S.; Pinter, G.; Mosavi, A.; Semperger, S. Sustainable Banking; Evaluation of the European Business Models. Sustainability 2020, 12, 2314. [CrossRef]

48. Rotondo, F.; Corsi, K.; Giovanelli, L. The social side of sustainable business models: An explorative analysis of the low-cost airline industry. J. Clean. Prod. 2019, 225, 806-819. [CrossRef]

49. Wagner, O.; Adisorn, T.; Tholen, L.; Kiyar, D. Surviving the Energy Transition: Development of a Proposal for Evaluating Sustainable Business Models for Incumbents in Germany's Electricity Market. Energies 2020, 13, 730. [CrossRef] 
50. Watanabe, E.H.; da Silva, R.M.; Junqueira, F.; dos Santos Filho, D.J.; Miyagi, P.E. An Emerging Industrial Business Model considering Sustainability Evaluation and using Cyber Physical System Technology and Modelling Techniques. IFAC-PapersOnLine 2016, 49, 135-140. [CrossRef]

51. Zhao, X.; Chen, L.; Pan, W.; Lu, Q. AHP-ANP-Fuzzy Integral Integrated Network for Evaluating Performance of Innovative Business Models for Sustainable Building. J. Constr. Eng. Manag. 2017, 143, 04017054. [CrossRef]

52. Nicoletti Junior, A.; de Oliveira, M.C.; Helleno, A.L. Sustainability evaluation model for manufacturing systems based on the correlation between triple bottom line dimensions and balanced scorecard perspectives. J. Clean. Prod. 2018, 190, 84-93. [CrossRef]

53. Figge, F.; Hahn, T.; Schaltegger, S.; Wagner, M. The Sustainability Balanced Scorecard-linking sustainability management to business strategy. Bus. Strateg. Environ. 2002, 11, 269-284. [CrossRef]

54. GRI-Standards: Amsterdam, The Netherlands. 2016. Available online: https://www.globalreporting.org/standards/ (accessed on 25 August 2021). 